\title{
THE IMPACT OF ACCOUNTING INFORMATION SYSTEMS ON UNDERSTANDING BUSINESS PROCESSES
}

\author{
Laura Barna1, Bogdan lonescu² \\ ${ }^{1}$ Bucharest University of Economic Studies (PhD student, Doctoral School of Accounting), \\ Bucharest, Romania \\ ${ }^{2}$ Bucharest University of Economic Studies (prof. univ. dr. at Management informatics \\ department, Faculty of accounting and management informatics), Bucharest, Romania \\ barnalaura15@stud.ase.ro \\ bogdan.ionescu@cig.ase.ro
}

\begin{abstract}
The business environment has evolved over time, so that it has become a dynamic and hyper-competitive environment. The business environment presents many risks. The purpose of the risks is to highlight the success or failure in the business, because some risks are inevitable and some risks can be controlled by companies. For a company to succeed and survive in a dynamic and hyper-competitive business environment, they must find and introduce radical and incremental innovations simultaneously.

Over time, many small, medium and big companies have succeeded in implementing accounting information systems, in order to make their activity more efficient. Investing in accounting systems has a positive impact on the company because they improve the efficiency and effectiveness of the organization, as well as increase the performance. Increasing efficiency and effectiveness means better management and dissemination of information within the company, so that employees have easier access to information and based on them to take the best decisions.

The research method used was quantitative using the questionnaire based on which we identified the main advantages and disadvantages of using accounting information systems, as well as the influence of these systems on the organization and the criteria underlying the choice of these systems. The most relevant results we obtained through our research were: accounting information systems offer both advantages and disadvantages, these systems improve the performance of the organization, and the criteria for choosing these systems depends most on the speed of implementation of the systems.
\end{abstract}

Keywords: efficiency, performance, information system, decision, business process, environment

JEL Classification: M15, M19, M41

\section{Introduction}

The business environment in the case of economic transactions is a complex concept that takes into account all the relations and internal and external factors of the companies. This environment has 2 components: an internal component (presents the way of organizing and managing the resources of a company to optimize the business according to the strategic mission and objectives of the company, but also for the most efficient use of resources) and an external component (the relations that are established between the company and the economic operators participating in different commercial transactions and other structural components of the national economy). 


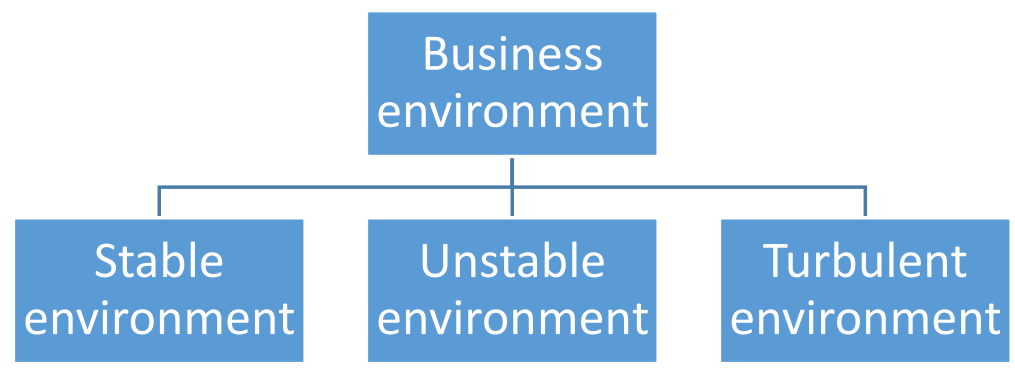

Figure 1: The three forms of business environment

Source: Author's own creation

Business processes are dynamic and constantly changing. According to Meiryani (2015), business processes are the main activities of a company, as a result of which information is processed that will appear in various reports that substantiate the decision-making process. For some companies, this environment can be considered simple or complex, stable, unstable or turbulent (see figure 1). The stability and complexity of the business environment affect the structure, the managerial style, but also the organizational culture.

Most of the time, companies are unprepared to meet the risks. The main risks to which companies are exposed are risks of a political nature (legislative changes) that can influence the activity of the company. For a company to succeed and survive in a dynamic and hypercompetitive business environment, they must find and introduce radical and incremental innovations simultaneously. This is where the investment in accounting information systems comes in, to help companies to manage and organize their activity as efficiently as possible. The article is structured as follows: a short presentation of the literature review where we presented the main concepts of the article refers on accounting information systems and business environment, a short presentation of the research methodology used in this article, analysis of the main results obtained based on the questionnaire and a short conclusion of the article.

\section{Literature review}

At the beginning of the last century, IT technologies began to be used in economic activities. Information systems could be used in the field of accounting, as this is the main source of economic information of a company.

The computerization of the accounting information system was tempered by the internal control, being guided by the internal audit and guided by the financial audit. The use of solutions based on information technology in the activity of companies has evolved from the option stage to the necessity stage. Initially, this system was used only for bookkeeping repetitive economic transactions, but this system has developed over time due to the accelerated evolution of technology, becoming an information system for internal and external users.

Innovation is the element that leads to better performance of companies and the reduction of financial and organizational obstacles, making it possible to access capital markets.

"Accounting Information Systems (AIS) are a tool which, when incorporated into the field of Information and Technology systems (IT), were designed to help in the management and control of topics related to firms' economic-financial area." (Grande et. al, 2011) 
The Accounting Information System is considered to be one of the most important systems of any organization because it can be identified in three components, namely the information system, the "business language" and the source of financial information (Wouters \& Verdaasdonk, 2002). After processing the financial-accounting information, decisions can be taken and the legal obligations can be fulfilled.

The purpose of Accounting Information System (AIS) is to automatically process the underlying accounting information. Facilitates the communication of financial information both inside and outside the organization. "The effectiveness of the AIS is measured by its ability to provide essential service, such as customer billing and payroll, and to meet the informational needs of its users and must provide accurate, trustworthy information to its users in a time frame, and in a form, that are relevant to their needs. It must include suitable internal control to protect the integrity of the information, to protect the resources of the enterprise" (Saeidi \& Prasad, 2014:57).

Accounting information is useful for the decision-making process. Accounting allows managers to explain decisions made in a language common to all information users. After the implementation of the accounting systems in the companies, there was an improvement of the decision-making process, of the internal controls and of the quality of the financial reports, thus facilitating the process of the company's transactions (figure 2).

The information systems have a role in the companies supporting the organizational efficiency and encourages the innovation and the change of the business model. The information system can influence the competitiveness of a company as follows:

- sustaining operational efficiency

- innovation of the business environment and change of the business process.

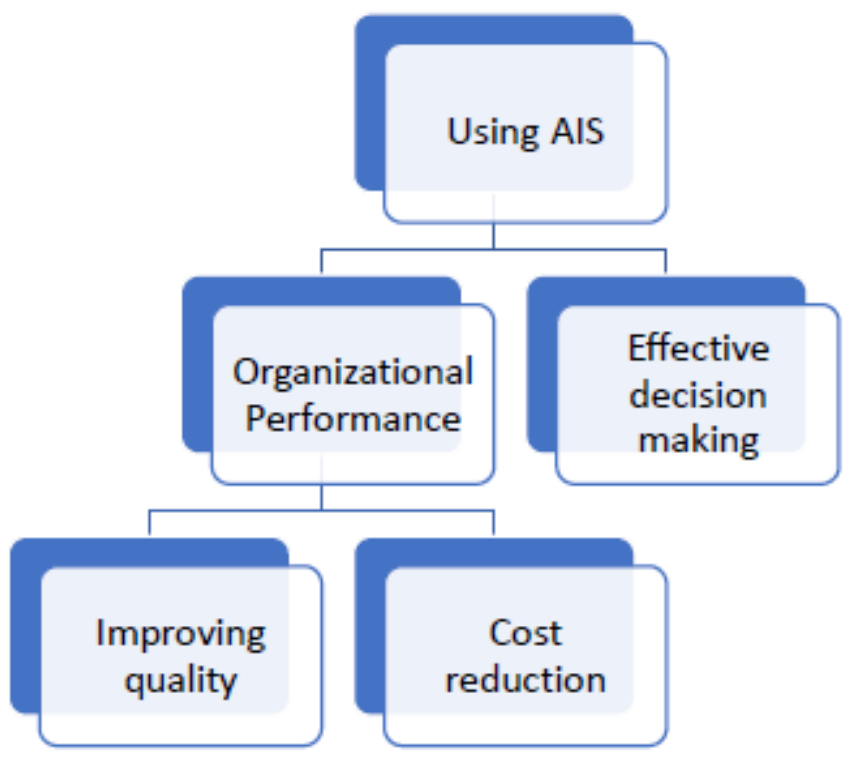

Figure 2: Using AIS

Source: Author's own creation

According to Fitriati and Mulyani (2015:170), AIS is an essential tool for an organization "to provide added value" and to provide "competitive advantages for the organization". The functions of these AIS provide important information that substantiates the decision-making process, thus ensuring better planning, management and control over the activity. Bodnar and Hopwood (2004, cited by Fitriati and Mulyani, 2015) consider AIS to be "a collection of 
$\overline{\text { data, processes and procedures" that provide essential information for users of financial- }}$ accounting information.

Grande et al. (2011) state that there is a positive relationship between AIS and performance, as they increase productivity and provide flexibility.

\section{Research methodology}

In this article I used quantitative research using a questionnaire in order to analyze the impact of the use of accounting information systems on business processes. This type of research is used on explaining human behavior and the factors that determine it. The questionnaire consists of a set of ten questions structured in a section containing demographic questions and a section containing questions specific to the research topic of the article, to which answered by $14 \%$ males and $86 \%$ females, with age between 20 and 27 years. The sample of respondents consisted of students from Bucharest University of Economic Studies and employees in the economic field.

The main research questions were:

Q1: What is the most significant influence regarding the use of accounting information systems within an organization?

Q2: What are the criteria used to choose an accounting information system?

Q3: What type of company do you think should implement accounting information systems? In the next section we will analyze the answers obtained based on the questionnaire.

\section{Findings}

Following the research conducted based on the questionnaire, we obtained the following results for the demographic questions that are represented in figure 3:

\section{DISTRIBUTION OF RESPONDENTS BY AGE}

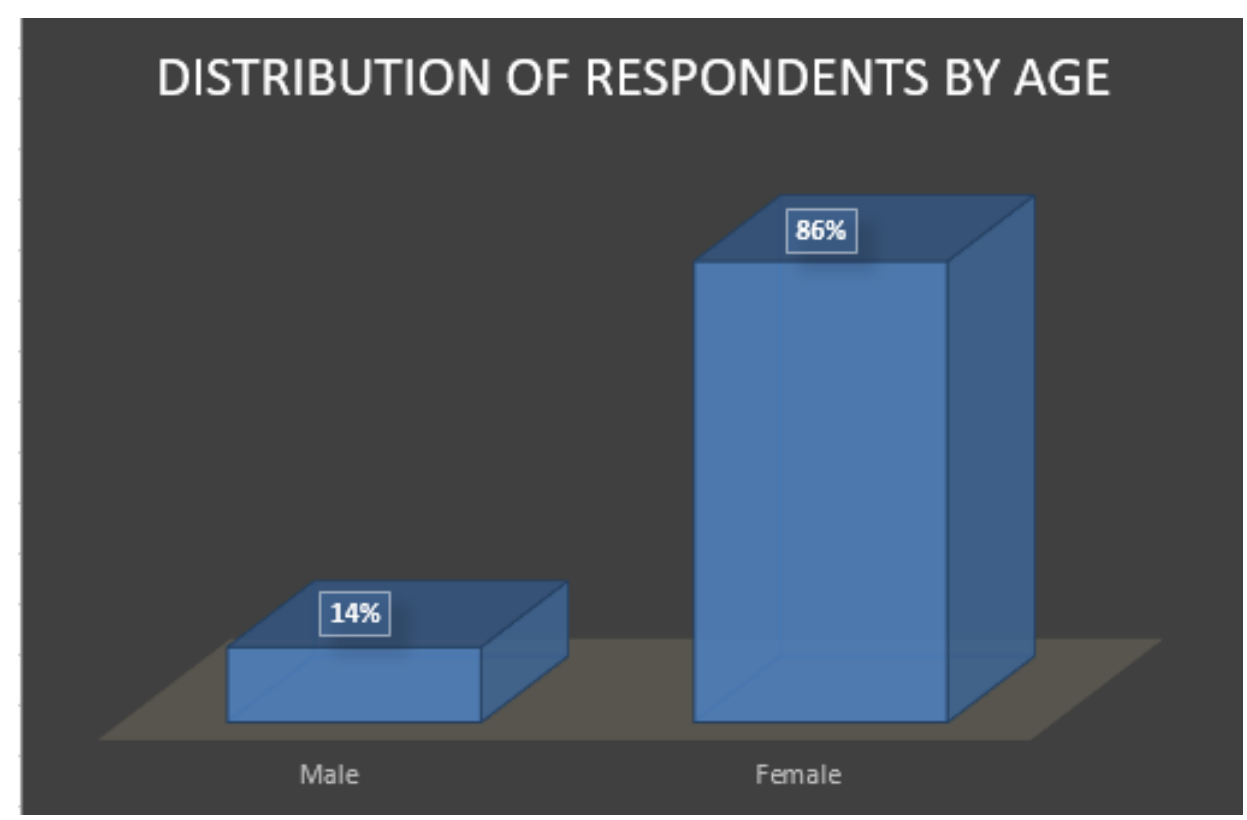

Figure 3: Distribution of respondents by age

Source: Author's own creation

According to the figure 3, most respondents are female, as most students and employees in economics are female according to a study conducted by ANS in 2020. 
To the questions specific to the research topic of the article, we identified that $44.4 \%$ of the respondents have an experience in using accounting systems of less than 6 months, the rest of the respondents having an experience between 1 and 5 years.

Q1: What is the most significant influence regarding the use of accounting information systems within an organization?

Accounting information systems have the main role of influencing the performance of the organization because the processed data are much more reliable, accurate and provide managers with a much more accurate information on the situation of the organization. Through the information generated by these systems, managers make the best decisions regarding the company.

Employee involvement is a very important component in improving the organization's performance. If they are responsible for the continuous improvement of the results and the services offered to the clients then the performance will improve significantly.

\section{Q2: What are the criteria used to choose an accounting information system?}

The criteria on the basis of which an accounting information system is chosen are: the speed with which the system is implemented, design friendly, the possibilities of personalizing the system according to the specifics of the clients that the organization has in its portfolio, the cost of the accounting and installation system. in operation, as well as whether this system provides templates to guide users of financial accounting information in the use of the systems.

According to Senior Software (2021), the implementation duration of an accounting information system depends on the size of the company, the number of users, the number and complexity of modules and the level of changes made to the program (customizations). Before starting the implementation of the system, the company must ensure that it has a well-structured IT infrastructure so that the implementation can be done as quickly as possible.

Q3: What type of company do you think should implement accounting information systems? According to the results obtained based on the questionnaire, large companies should implement these accounting information systems. A large company has more resources to cover the costs of acquiring and implementing the accounting information system.

The accounting information systems implemented within the organization must be flexible so as to adapt to the volume of transactions and organizational changes within the organization. The costs associated with the effort or financial investment required to modify and maintain the IT infrastructure must be offset by the benefits offered by the company's IT products (Palade \& Tanasă, 2016).

Accounting information systems offer the company the opportunity to better organize its business activities by paying "increased attention to the company's main objectives and customer requirements" (Kennedy \& Brewer, 2005).

According to the study conducted by Thapayom \& Ussahawanitchakit (2015), the mathematical errors created by manual information processing are reduced with the automation of company processes. Thus, financial reports are generated more easily and in a timely manner, and managers make decisions much easier because the information is much clearer and much easier to understand.

According to Elbashir et al. (2008), the added value of the business following the implementation of accounting information systems can be classified on 2 levels:

- The performance of business processes that include the benefits of using these systems

- The performance of the organization that includes characteristics of the strategy established by the company and the way in which the objectives are managed. 
According to Workwise.com (2020), the main benefits of implementing accounting information systems on business processes are:

- data security using various mechanisms to prevent unauthorized access to confidential company data

- $\quad$ increase productivity because it eliminates redundant processes

- $\quad$ streamline because it automates all the processes within the company

- offers mobility and flexibility so that employees can work regardless of location (office, home) or any device (phone, tablet, laptop, PC)

- $\quad$ offers the user the possibility to make forecast reports

Table 1. Advantages and disadvantages of accounting information systems

\begin{tabular}{|c|c|}
\hline Advantages & Disadvantage \\
\hline $\begin{array}{ll}\text { - } & \text { easy to use } \\
\text { - } & \text { efficient management of the } \\
\text { activity } \\
\text { - } \quad \text { intuitive } \\
\text { - } \quad \text { good structuring of modules }\end{array}$ & $\begin{array}{ll}- & \text { may have resolution issues } \\
\text { - } & \text { high setup costs }\end{array}$ \\
\hline
\end{tabular}

Source: Author's own creation

\section{Conclusion}

Given that the business environment is very dynamic and constantly changing, an organization must implement IT systems to help the organization more easily carry out its planned activities.

Manual activities have been replaced by the use of efficient accounting information systems, so as to provide clear and transparent information.

In conclusion, accounting information systems have a major impact on improving business performance, because they offer benefits to the company and especially the opportunity to grow.

\section{References}

1.ANS (2020), Platforma națională de colectare a datelor statistice pentru învățământul superior [online]. Available: https://date.invatamant-superior.ro [January 5, 2021]

2.Elbashir, M.Z., Collier, P.A., Davern, M.J. (2008), Measuring the effects of business intelligence systems: The relationship between business process and organizational performance, International Journal of Accounting Information Systems, vol. 9, pp. 135-153

3.Fitriati, A., Mulyani, S. (2015), The Influence of Leadership Style on Accounting Information System Success and Its Impact on Accounting Information Quality, Journal of Finance and Accounting, vol.6, no.11: pp. $167-174$.

4.Grande, E.U., Estebanez, R.P., Colomina, C.M., (2011), The impact of Accounting Information Systems (AIS) on performance measures: empirical evidence in Spanish SMEs, The International Journal of Digital Accounting Research, vol. 11, 2011, pp. 25 - 43.

5.Kennedy, F.A., Brewer, P.C. (2005), Lean Accounting: What's It All About?, Strategic Finance, vol. 87, nr. 5, pp. 26-34

6.Meiryani, M.S. (2015), Influence Business Process On The Quality Of Accounting Information System, International Journal of scientific \& Technology Research, vol. 4, pp. $323-328$

7.Palade, D.P., Tanasă, F.E., (2016), Impactul tehnologiilor informaționale asupra sistemelor de contabilitate, Available: https://www.ceccarbusinessmagazine.ro/impactul-tehnologiilorinformationale-asupra-sistemelor-de-contabilitate-a925/ [April 10, 2021] 
8.Saeidi, H., Prasad B. (2014), Impact of Accounting Information Systems (AIS) on Organizational Performance: A case Study of TATA Consultancy Services (TCS) - India, Uct journal of management and accounting studies, 2014, vol. 03, pp. $54-60$.

9.Senior Software.ro (2021), Cat dureaza perioada de implementare? Care sunt factorii de care depinde o implementare de solutii informatice?, Available: https://www.seniorsoftware.ro/cat-dureazaperioada-de-implementare-care-sunt-factorii-de-care-depinde-o-implementare-de-solutii-informatice/ [April 11, 2021]

10.Thapayom, A., Ussahawanitchakit, P. (2015), Accounting Information System Excellence and Goal Achievement: Evidence from Information and Communication Technology Businesses in Thailand, The Business and Management Review, vol. 7, pp. 309-321.

11.Workwise.com (2020), Benefits of implementing ERP systems, Available: www.workwisesoftware.com [November 15, 2020]

12.Wouters \& Verdaasdonk (2002), Accounting Information Systems, Advances in management accounting, Publishing house: Emerald Books, vol. 21, pp. 183-188. 